\title{
FAMILIAL INCIDENCE OF CONGENITAL ABNORMALITIES OF THE ANUS AND RECTUM
}

\author{
BY
}

\author{
P. V. SUCKLING, M.B., M.R.C.P.
}

Late Paediatric Registrar, University College Hospital

Congenital abnormalities of the anus and rectum are among the rarer congenital anomalies, the incidence being variously given as one in five thousand to one in ten thousand live births (Dmytryk, 1945). Murphy (1947) in Philadelphia in his study of 890 dead children with diagnoses of gross congenital malformations and consequent assessment of their families with an addition of forty-five cases, reports ten cases. Under the care of University College Hospital in the past twenty years there have been 28,443 deliveries, and four cases of anomalies of the anus and rectum have been recorded. Feggetter (1939) records uniovular twins with imperforate anus and notes a twinning tendency in the family, but records no further instance of anal anomaly.

\section{Case History}

The baby, the first-born and a boy, was delivered by forceps extraction for delay in the second stage of labour, and weighed $7 \mathrm{lb} .3 \frac{1}{2} \mathrm{oz}$.

There had been no maternal illnesses during pregnancy. The mother was aged 28 , her Wassermann reaction was negative and her $R h$ factor positive. Her haemoglobin was 60 per cent. There had been no irradiation of either parent.

The infant began to gain weight from birth, and by the fifth day had increased by $8 \frac{1}{2} \mathrm{oz}$. Pitting oedema was observed at the knees for which no cause was found. The urine was normal, and serum proteins were $6.8 \mathrm{~g}$. per $100 \mathrm{ml}$. of blood, with albumin $4 \cdot 2 \mathrm{~g}$. Blood urea was $24 \mathrm{mg}$., and plasma chlorides $575 \mathrm{mg}$. per $100 \mathrm{ml}$. Urine and meconium had been passed normally.

On the eighth day some abdominal distension was noted, but no ascites was detected and the oedema disappeared. He was taking well from the breast and a few curds were seen in the motions, which were rather frequent but not regarded as abnormal. His weight was now $17 \frac{1}{2} \mathrm{oz}$. above his birth weight. His haemoglobin was 132 per cent., with red cells $6,500,000$ per c.mm. of blood, white cells 16,600 per c.mm., neutrophils 39 per cent.

On the 9th day there was marked distension of the abdomen and visible peristalsis of the large bowel. An attempt was made to pass a finger up the anal canal, but an obstruction was encountered at a depth of about half an inch. A rectal thermometer

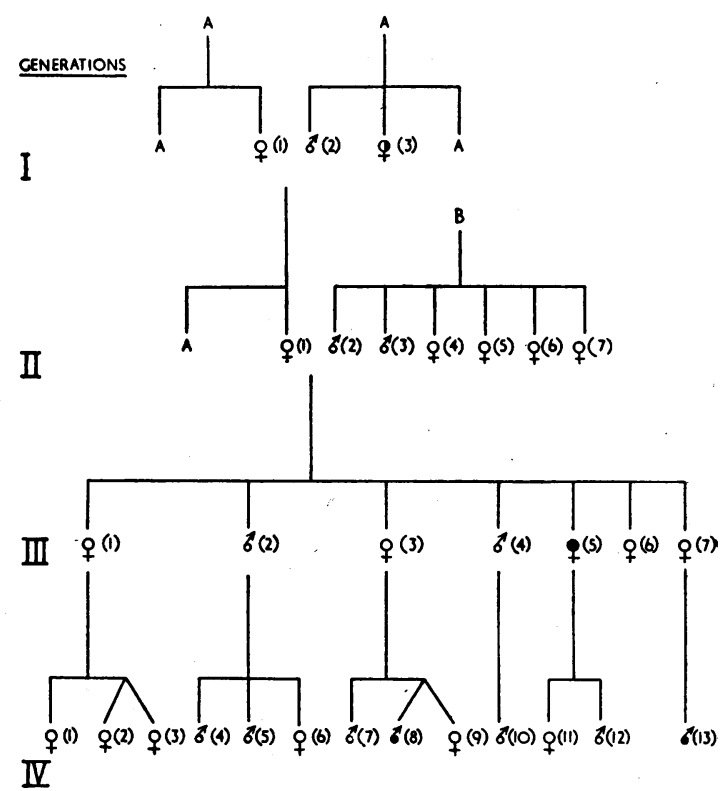

$O=$ apparently normal cases. $\Phi=$ doubtful cases. $O=$ proved cases. A signifies a Russian family, of which the details are not known. The other family is English.

The generations are given as I, II, III, and IV. Members of the family are referred to by their generation, and consecutive numbers are given in parenthesis.

I. 1-3: Dead-potential ages unknown.

II. 1: fifth child, aged 70 .

II. 2: dead, potential age 70 .

II. 3: aged 58, alive.

II. 4:, 56, ,

II. 5: " 54, ,

II. $\quad$ 7: dead, potential age 49

III. 1: aged 51 , alive.

III. 2: ", 48, ",

III. 3: " 43, ",

III. 5: ", 37, ",

III. 6: " 31 , ",

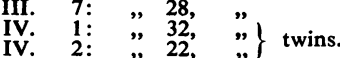

IV. 2: " 22, "

IV. 3: " 2 22, ",

IV. 5: ", 20, ",

IV. 6: " 12,

IV. 7: " 18, ",

IV. 8: ", 12, dead. $\}$ twins.

IV. 10: " 12 , alive.

IV. 11: ", 12, ",

IV. 12: " 10,

IV. 13: patient.

There is no consanguinity in any of the unions recorded above. 
could likewise not be passed. The baby's general condition was quite good, and faecal matter was still being passed in small quantities, but vomiting had begun. A radiograph showed gross distension of the colon with gas.

Operation was undertaken without anaesthesia. A raphé of skin passing antero-posteriorly divided the anus, but not the anal canal, into two. This raphé was cut and a silver probe was passed through a small opening in the recto-anal membrane, with escape of gas and immediate lessening of the intra-abdominal tension, which had been considerable.

The opening was dilated with gum elastic bougies and in later days with Hegars dilators, until the little finger could be inserted. At first the opening tended to seal itself off with faecal matter, necessitating frequent insertions of a rubber catheter.

After operation the baby's condition was fair, but vomiting continued and intravenous nutrition was required for thirty-six hours. Apart from this and a little mucus in the stool for a few days the baby made an uninterrupted recovery. The stenosis is now judged to be about half an inch deep to the external anal margin, and to be about half an inch long. It corresponds therefore to Type I of Ladd and Gross (1941). A barium meal has not been given, but it appears unlikely that there is any further stricture of import in the rest of the bowel. Radiographs of the pelvis, lumbar and sacral spines, and coccyx have disclosed no abnormality.

After the facts of the baby's illness had been explained to them, the family history was elicited from the parents (see chart). There are no known congenital abnormalities on the father's side; and, so far as can be told, other congenital abnormalities have not occurred.

\section{Comment}

Case I (3) is a doubtful case occurring in Russia :some seventy years ago. Case III (5) has been interviewed and apparently had a rectovaginal fistula operated upon at the age of six months. She has had no further disability, and she declined examination. Case IV (8) died in a London hospital at the age of five months following measles. Confirmation has been obtained that he had an imperforate anus at birth which was operated upon and was apparently similar in type to this patient's. Case IV (13) is this patient.

Comment by Dr. H. Harris, the Galton Laboratory, University College. The occurrence of four cases of such a rare congenital anomaly in a single family group strongly suggests that we are dealing with an inherited trait. The configuration of the pedigree indicates that the anomaly is probably determined by a single gene which is 'conditionally' dominant but incompletely manifesting. The affected individuals are presumably heterozygous for the gene.

The occurrence of the trait in successive generations and the absence of any consanguineous matings rule out the possibility of simple recessivity. There is no suggestion of sex linkage or sex limitation.

I would like to thank Dr. R. E. Bonham-Carter, under whose care this patient is, and Mr. Merrington of the Surgical Unit for their advice and help with the treatment.

\section{REFERENCES}

Dmytryk, E. T. (1945). Arch. Surg., 50, 253.

Feggetter, S. (1939). Newcastle med. J., 19, 20.

Ladd, W. E., and Gross, R. E. (1941). Abdominal Surgery of Infancy and Childhood. Saunders. Philadelphia and London.

Murphy, D. P. (1947). Congenital Malformations. Lippincott. Philadelphia. 